\title{
Political symbolism as policy craft: explaining non- reform in South African education after apartheid
}

\begin{abstract}
The policy literature in developing countries is replete with narratives of 'failure' attributed to the lack of resources, the inadequacy of teacher training, the weak design of implementation strategy, and the problems of policy coherence. This research on education policymaking after apartheid presents the following puzzle; what if the impressive policies designed to change apartheid education did not have 'implementation' as their primary commitment? Drawing on data from seven detailed case studies, the construct of 'political symbolism' is proposed as a first step towards developing a more elaborate theory for explaining one of the most intractable problems in policy studies; the distance between policy ideals and practical outcomes.
\end{abstract}

This research represents a theoretical experiment designed to explain education reform under conditions of social transition using the construct of political symbolism. The origins of the larger study ${ }^{1}$ of which this article represents a small part, lies in a puzzle: despite unprecedented investments in policymaking and policy production in the years anticipating and following the end of legal apartheid in South Africa, there appears to be very little change in the daily routines of schools and classrooms of the nation. Earlier surveys suggest that a significant part of the explanation for the distance between policy and practice lies outside of conventional factors attributed to education reform under third world conditions: the lack of capacity within the new state, the large numbers of under-qualified teachers, or political resistance within conservative white communities (Jansen and Naidoo 1996, Kahn 1996, Samoff 1996, Jansen 2001).

The purpose of this article, therefore, is to use the evidence yielded through seven case studies of education reform (Jansen 2000) to answer the principal research question: why is it that despite the production of literally thousands of pages of formal policy documents after apartheid, there is so little change in school and classroom practice throughout South Africa? I will not repeat the considerable evidence pointing to the policy - practice 'gap' within South African education since the end of apartheid and the inauguration of a Government of National Unity in April 1994, led by the first President of a democratic South Africa, Nelson Mandela. Such evidence is available in abundance (Kallaway et al. 1998, Manganyi 2001, Hartshorne 1999, Kahn 1996, Jansen and Christie 1999, Maharaj 1999, Pendlebury and Enslin 1999, Sayed and Jansen 2001). What is lacking in the available literature are new explanations for this distance between policy and practice - other than the well- trodden assumption that 'if only there were more resources', education reform in poor countries could expect greater fidelity between policy (what government officials intend) and practice (what actually happens in classrooms).

In the first part of this article I provide the evidence for understanding the policy - practice gap through the lens of 'political symbolism'. I will then venture contextual explanations for the emergence and, indeed, the continuation of symbolic policy as preferred strategy in the transition from apartheid education. And I will conclude by evaluating the theoretical dilemmas and possibilities offered by political symbolism for understanding 
non-reform under conditions of transition. In this task, I draw on some of the comments made by 'critical readers' on an earlier version of this article.

\section{Making the case: political symbolism as policy craft}

The making of education policy in South Africa is best described as a struggle for the achievement of a broad political symbolism that would mark the shift from apartheid to post-apartheid society. We search in vain for a logic in policymaking connected to any serious intention to change the practice of education 'on the ground'. A focus, therefore, on the details of implementation will not be fruitful since it will miss the broader political intentions which underpin policymaking after apartheid. Every single case of education policymaking demonstrates, in different ways, the preoccupation of the state with settling policy struggles in the political domain rather than in the realm of practice. This theoretical postulation is important since it enables candid reassessment not only of the purposes of policymaking, but also of the pace and direction of educational change. How has this position been arrived at? First, by examining closely the relatively few unguarded statements of senior bureaucrats and politicians themselves in their explanations for the failure of education policy to connect to the lives of teachers and learners in schools and classrooms. The most clear and remarkable concession in this regard was provided by a senior policy-maker in the education bureaucracy, Dr Ihron Rensburg (Deputy Director General, Education). The occasion was the National Policy Review Conference of the dominant political party in the country, the African National Congress (ANC) and allied movements in October 1998. According to Dr Rensburg:

I am suggesting that we consider a typology which speaks of an overtly ideological political period (1994-1999) [which reflected the shift from an apartheid ideology and polities, replete with its minority rule, balkanised, racially defined and resourced organisations, institutions and governance, to a democratic order marked in particular by non-racialism. (Rensburg 1998:50)

This period should be distinguished, according to Rensburg, from the next period (1999-2004) which concerns 'consolidation and deep transformation' (Rensburg 19898: 50). The first period, therefore, was simply about establishing the ideological and political credentials of the new government.

\footnotetext{
Naturally, this period could not but focus on the establishment of new organisations, institutions and governance, as well as new resourcing patterns. During this period ... many successes were recorded. These are reflected in the many policy papers, legislation, regulations and norms and standards which have been developed and announced. (Rensburg 1998:50)
}

This remarkable paper, in which the periodization coincides neatly with election years, could be cynically dismissed as political opportunism. Except that this understanding was not limited to the state and its officials. In one of two responding papers, a senior official of the largest teachers union in the country (SADTU or the South African Democratic Teachers Union), Aubrey 
Mathole confirms Rensburg's rendition of the first four years with an insertion pertinent to the theoretical position of this paper.

In his characterisation of the two periods (1994-1999 and 1999-2004). We would like to add the word 'symbolic' to the first period because our government had to practically display a rapid departure from the apartheid education system. (Mathole 1998:66)

But Mathole immediately seizes on this opportunistic typology. 'The impression given by this chronology is that delivery will only come after the elections. Is there any guarantee?' (Mathole 1998: 60).

Chisholm and Fuller rightly conclude their analysis on 'the centering and narrowing of educational policy agenda' (Chisholm and Fuller 1996: 693) in South Africa by acknowledging the prominence of the symbolic:

national and provincial policy makers display a rich tapestry of policy symbols signalling mass opportunity, but they are stitched together with a thin thread. In the first two years of the GNU (Government of National Unity) this has unsolved the NQF (National Qualifications Framework), a promise of 'lifelong learning', expansion of adult literacy programmes and renovated buildings in townships. But the effectiveness of local schools will not magically increase if the policy agenda remains centred on symbols of opportunity. (Chisholm and Fuller 1996: 714)

Unfortunately, their analysis does not expand on or explain the ways in which such a policy orientation (political symbolism) emerges, for what reasons, and with what consequences for educational practice and politics. In fact, their theory of policymaking and change resides in a forced marriage of two competing explanations: international political economy (the ways global economic and political changes influence policy choice) and institution theory (the process which define how 'fragile states' position themselves to appear modem and gain broad legitimacy). There is two much incoherence in this explanation for which policies 'rise to the top'. My point, however, is that there clearly is a recognition by policymakers and policy analysts of a politics of symbolism at play in policy development which is disconnected from immediate concerns about educational practice.

Second, the prominence assigned to the symbolic value of policy is revealed by the way that politicians and the public lend credence and support to the production of policy itself rather than its implementation. This symbolic value of policy was not lost on the second Minister of Education (Professor Kader Asmal) taking office in May 1999 with considerable public confidence based on his track-record in his former portfolio, the Ministry of Water Affairs and Forestry. In Kader Asmal's 'Call to Action', a comprehensive policy statement following five weeks of what his officials called 'a listening campaign', he claims the following:

I was told by everyone I met that we have created a set of policies and laws in education and training that are at least equal to the best in the world . . I am proud that our young democratic government, after inclusive and genuine consultation, has built a national consensus around the main education policy positions of the mass democratic movement... The most important thing about building consensus for a 
policy or a law is that people own it and want to make it work. Implementation takes time... (Asmal 1999:2 emphasis added)

In forum after forum, South Africans have been praised for the promulgation of policy, its sophistication and quality (see Cloete and Muller 1998: 534). A striking though not uncommon example is an observation made in the Higher Education Review (1996) with respect to the report of the National Commission on Higher Education (NCHE):

International experts have described the NCHE proposals for reform as one of the best tertiary education policy documents ever wntten, but liaoe questioned the goversisnes;t 's ability to implement them. (Cloete and Muller 1998: 1 emphasis added)

It is this hailing of written or declared policy, albeit with a footnote of scepticism about implementation, that has reinforced the notion of the political importance of the formal statement of policy in South Africa.

This political investment in the production of policy was especially important to politicians in selling their advantage to the broad democratic alliance. At the National Policy Review Conference on Education and Training (1998), the first Minister of Education after Apartheid, Professor Sibusiso Bengu, held forth the following line to comrades:

The ANC-led government of national unity came into office with a substantial set of policies which outweighed everything put to the electorate by all the ANC's opponents collectively. These policies grew out of the work of the NECC (National Education Coordinating Committee), the EPU's (Education Policy Units), the NEPI (National Education Policy Investigation) reports, the National Education Conference, the 'Ready to Govern' Policy Conference of the ANC, the COSATU-led (Congress of South African Trade Unions) National Training Policy Initiative, and the CEPD (Centre for Education Policy Development) under the direction of the ANC education desk...we must ask ourselves whether the ANC alliance, or a broader alliance of democratic forces could undertake anything comparable in 1998 or 1999 ? An equally important question is whether we need to do so? (Bengu 1998: 31)

Third, the symbolic role of policy is displayed by the ways in which policy pronouncements make reference to issues of implementation. Where policy and planning are strongly connected, one would expect a government bureaucracy to outline concrete steps that would be taken to implement such policies. Such implementation plans need not accompany the immediate policy announcement, but would typically follow soon after. This has seldom happened in the seven case studies around which this theory of political symbolism is built (Jansen 2000). In reflecting on the non- implementation of government's flagship programme for the reform of apartheid education, Curriculum 2005, Minister Asmal's explanation is also a concession:

It was unfortunate in the extreme that the inaugural year of Curriculum 2005 (1998) coincided with the crisis in provincial budget management, with the result that the preparation of most provincial education departments was seriously compromised, or even disrupted. In both 1998 and 1999, new materials in support of the curriculum reached the schools late in the year, despite President Mandela's directive. (Asmal 1999: 13) 
Yet this explanation simply shifts blame to the provinces and publishers without giving insight into the national policymaking and planning processes which led to the non-implementation of the new curriculum.

This may be a tradition in policymaking that will continue into the next century. South Africa's fascination with new policy statements, rather than their implementation, may continue to constitute the dominant mode of policy engagement in education. The development of the ANC's Policy Framework on Education and Training (ANC 1994) was heavily criticized for lacking an implementation plan. This criticism led to IPET, the Implementation Plan for Education and Training, which was largely ignored by the first post-apartheid government. Little has changed. Dramatic policy announcements and sophisticated policy documents continue to make no or little reference to the modalities of implementation.

Furthermore, when policy implementation does appear on the agenda, it is often as a last minute concession or as a way of muddling through difficulties experienced in practice within a new policy. In the case of C2005, the lastminute concession to offer each Grade 1 teacher three to five days of training (or information) on the new curriculum was not accompanied by any detailed sense of how these teachers would actually implement radical new ideas in under-resourced classrooms. These sessions therefore became the opposite of the pedagogy they espoused: 'telling sessions' rather than 'learning by doing' workshops. The late introduction of the cascade model i.e., that a small group of trainers will train facilitators who will train teachers who carry these messages down to the classroom with other teachers, was poorly conceptualized (Chisholm 2000). The assumption that a curriculum message (or any information) passes in an unproblematic manner down a cascade where persons have varying levels of capacity and experience, was flawed from the beginning. In short, implementation was not an advanced planning tool, but something improvised even as policy was being introduced to teachers.

The most dramatic illustration of policy implementation being constructed through and during crisis is the case of the teacher redeployment scheme (Jansen 1999). At national and provincial level there was simply no coherent, thought-out policy implementation apparatus for the teacher redeployment scheme. With the first legal challenge, the flaws in the policy were seriously exposed despite an elegant and highly symbolic policy proposal to shift teachers from privileged schools to disadvantaged institutions. The costs and chaos which erupted are now a matter of public record (Jansen 1999).

In most cases, however, implementation was never on the policy agenda at all. The syllabus revision process was simply about achieving a symbolic and visible purging of the apartheid curriculum in order to establish legitimacy for an ANC-led government under unprecedented criticism for failing to deliver in education. There was no implementation plan. How would schools receive the revised syllabi? To this day, most schools in South Africa do not have access 
to the revised syllabi. In addition, many of the syllabi had not changed at all (Jansen 1998).

Fourth, the symbolic prominence of education policy is evidenced in the lack of integration of various national policy statements. There is very little policy coherence across the different White Papers and other official policy documents produced since 1994. One manifestation of this problem is that each policy process had its own agenda, actors and focus. At some point, each document had to address the provisions of the South African Qualifications Authority (SAQA) Act and the central issue of linkage to the National Qualifications Framework. But since the NQF came into being long after the other policy processes were being deliberated, it became a forced integration in many instances. The processes initiating Curriculum 2005 and its prescribed approach, Outcomes Based Education (OBE), do not make any reference to the NQF. For this reason, the application of the NQF to schools, training institutions, and the workplace are completely incoherent. Similarly, key players in the development of the NCHE experienced a compulsion, under heavy political pressure, to introduce the tenets of the NQF into their document when it was already near-completion. There is no reference to the provisions of the NQF in the syllabus revision process of late 1994. Indeed, the link between OBE and the NQF is simply not made explicit in any government documents. One reason for this state of affairs is the fact that labour was pushing its own set of policies for the training sphere (the NQF and competency-based education) while education was generating separate policies for the school sector (Curriculum 2005 and outcomes based education).

The most puzzling manifestation of this problem of policy incoherence is the way in which the populists premises of People's Education (fore-grounding educational processes) ${ }^{2}$ came to constitute Curriculum 2005 while the regulatory language of competencies defined Outcomes Based Education (fore-grounding educational outcomes). This phenomenon has been described as:

a hybrid educational methodology which politically has sought to go beyond the narrow confines of competency models by incorporating the progressive pedagogic principles of people's education. This has created a learning methodology that is simultaneously radical in discursive practice yet behaviouralist in assessment technology. (Kraak 1998: 22)

Where the emphasis in policy is simply on getting-out the next set of legitimating documents, one cannot expect substantive coherence in these different documents.

Fifth, the symbolic investiture in policy is given credence in the way policy invokes international precedent and participants in the development of the various education policies. There are few countries in postcolonial Africa that has drawn more heavily on international consultants in its first few years of 'independence'. ${ }^{3}$ The prominent role of international consultants within South Africa and its validation at Salzburg in the case of the NCHE Report is welldocumented (Cloete and Muller 1998). The role of consultants from Australia, 
the UK, the USA, New Zealand and other areas in the development of various phases of Outcomes Based Education has also been documented (Jansen and Christie 1999). As Diphofa and his colleagues at the Joint Education trust recall:
With the reforming zeal and energy of a movement which has been in exile for almost half a century, the new government has seized upon progressive models in other countries and embodied these in curriculum 2005, the national curriculum to be followed in all the country's schools. This is a bold experiment indeed: nothing of its kind has ever been tried, on anywhere near this kind of scale, anywhere in the world. (Diphofa 1999:9)

In this regard, the role of American William G Spady cannot be underestimated in providing to the Department of Education a neat and elegant language for making the consumption of OBE accessible to practitioners. Overseas consultants played a crucial role in developing options for the financing of public education. The role of international consultants is particularly revealing of how international specialists come to influence local policy. Christopher Colclough and Paul Bennell were the two influential finance specialists influencing school funding policy. The following excerpt was constructed from an interview with Colclough (11 March 1999) parts of which I subsequently confirmed with Blade Nzimande (September 1999) ${ }^{4}$ :

\begin{abstract}
I was at first invited by John Samuel via the Centre for Education Policy Development in 1992/1 993 tube involved in education finance and policy discussions. I later played a role $\mathrm{m}$ the assessment of existing government positions, including an analysis of conservative reasoning behind budgets emanating from apartheid's officials (like Gert Steyn). This was the period of strategic management teams' during the early transition. I later engaged with the Department of Finance which I experienced as conservative and heavily influenced by World Bank thinking, especially among those responsible for social sector projects. I did play a role in influencing the governance debate leading to the White Paper by arguing that we needed to keep white and articulate blacks within the public sector as an arena for state influence. Hence, the soft option in financing alternatives that did not force the rather strong redistributive thrust of the Task Team. This I presented to Blade Nzimande in his capacity as Chair of the Parliamentary Portfolio Committee (on Education). The Committee was sceptical at first, but later realised that this matter affected not only white children but children of civil servants working in government. The notion was that there was a need to keep the black middle class involved in and as advocates for the public school sector.
\end{abstract}

This excerpt from an extended interview shows how international thinking came to influence a national policy decision spanning two government departments (Education and Finance) and parliament itself. My point here has less to do with the mechanics of policy but with the ways in which policy claims can then be justified through a set of international referents.

Halpin and Troyna, in their thesis on education policy borrowing as legitimation, correctly note that 'elected officials and politicians are more likely to be interested in a borrowed policy's political symbolism than its details' (Halpin and Troyna 1995: 307). And again, that 'the particularities of 
education policies are often less significant than their role in political discourse' (Halpin and Troyna 1995: 307).

Similarly, Roger Dale observes from his attempt at specifying globalisation effects on national policy, that 'The nature of its (globalisation) effects on education could be expected to be direct and they would tend to be restricted to ... the level of education politics' (Dale 1999: 10).

This legitimating of education policy through external referencing is further invoked through the lead-in paragraphs to every single White Paper in education. It is stated that education is required to deal with the reality of globalization, international technologies and expanding economic markets. The new citizen therefore is a global citizen, and the role of education is to induct learners into a world of expanding horizons. It is a vision of education that is forward-looking, competitive and global in its implications. This orientation of policy towards external legitimation is what Fuller, especially, calls 'institutional processes'.

How fragile governments must act to look modern and to gain wider legitimacy ... mimicking Western ways of doing defining policy problems and organising technocratic remedies ... the processes described and analysed are simultaneously material and symbolic. (Chisholm and Fuller 1996: 694)

Sixth, the symbolic role of policy is not restricted to the international participants and processes in policymaking. The very substance of policy itself validates the presence of South Africa as an actor within international education. In a short period of time, the South African state adopted educational discourses that were intimately and directly linked to current developments elsewhere in the international environment. So, for example, the crucial first White Paper on Education and Training (March 1995) locates South Africa among achieving global states:

\footnotetext{
Successfiul modern economies and societies require the elimination of artificial hierarchies, in social organisation, in the organisation and management of work, and in the way learning is organised. They require citizens with a strong foundation of general education, the desire and ability to continue to learn, to adapt to and develop new knowledge, skills and technologies... In response to such structural changes in social and economic organisation and technological development, integrated approaches toward education and training are now a major international trend in curriculum development and the reform of qualification structures. (Department of Education 1995a 15,21, my emphasis)
}

Consequently, the issues of lifelong learning, competency- and outcomesbased education, the integration of education and training, national qualifications frameworks, unit standards, authentic and continuous assessment, quality assurance etc are prominent signals of international location (Hartshorne 1998: 105-123). There is little chance of South Africa ever attaining or moving towards a lifelong learning system (through it appears in every policy document) and there will certainly not be an integration of education and training in any meaningful way. The 'unit standards' approach has been discarded within universities and there is a serious review of Curriculum 2005 within the second post-apartheid 
government - merely two years after its introduction into schools. Which authenticates the earlier claims that the implementation of a set of policies is of much less concern that its social validation.

Seventh, the emphasis of the South African state on the symbolic role of policy is expressed through the heavy attention paid to formal participation in the policy process irrespective of its final outcomes. Apart from the constitution-making process, this quality may have been pursued more aggressively in education than any other sector. Lodge (undated), in his review of 'policy processes within the ANC and the Tripartite Alliance"5 concludes that:

Policymaking within the Tripartite Alliance was participatory and even democratic in character up to the election. Since then, macro-economic policy making has become an increasingly circumscribed undertaking though $m$ other areas consultation continues to play an important role in the development of policies: education is a case in point and represents a field in which the ANC's own policy generating arrangements have remained quite effective. (Lodge undated: 42)

Lodge is correct. In every single process leading to the production of policy papers, and throughout the 1990s, there was an exceptional preoccupation with inclusivity and representivity in the make-up of working groups. ${ }^{6}$ In ANC and CEPD working groups, we spent an inordinate amount of time ensuring that there were enough representatives from the provinces, rural areas, women, black scholars, representation based on expertise and constituency, non-university contributors, and so on. It is this faith in process itself that granted legitimacy to policy, irrespective of the final outcome. It allowed bold public claims to be made back to loyal constituencies:

It would be invidious to single out the names of the comrades who contributed so much to all these efforts. There are too many. Some of them are here, and you know who you are. But, the policy drive of the democratic moment, and specifically the alliance, involved hundreds, if not thousands of women and men across the country. (Bengu 1999: 31)

Hundreds of teachers participated in the refinement of Curriculum 2005 and the development of attendant learning programmes. Throughout South Africa, representative groups constituted the syllabus committees. The Hunter Commission on School Governance dedicates a separate chapter in their final report to 'The Committees Process' (Chapter 2), recording in some detail the many visits, colloquia, workshops and seminars across the country, including 200 written submissions (Jansen 2000). This Commission itself consisted of representatives that included conservative and right-wing teacher bodies and political organizations. This was called, in South African parlance, a 'process'.

One important arena in which participation in policymaking became a public spectacle was through the Public Hearings convened by the Parliamentary Portfolio Committee on Education. The Chair of that Committee, Blade Nzimande, described the significance of this institution as follows:

One of the most exciting aspects of our work was the Public Hearings which we convened when new policies were being developed. These hearings not only 
engaged the broad public on matters of education policy but it also prevented Parliament from simply becoming a rubber-stamp of government policies This was no doubt the most exciting and innovative aspect of the new committee system. I found it very fulfilling, this process of critiquing government education policy. One example of where this worked very effectively was in the deliberations on the South African Schools Bill, later the Schools Act of 1996. The Public Hearings therefore gave the Parliamentary Portfolio Committee considerable power to impact on policy through effective public participation in the process. It should be remembered that this function (the Public Hearings) was something that the Department of Education did not necessarily have the capacity to conduct themselves, and so the Parliamentary Portfolio Committee became an important vehicle through which to secure this kind of public participation in policy... The one thing that I know my successor will continue is to keep the education proceedings and processes of parliament open to public scrutiny and input. That may in fact be the most important contribution of the first post-apartheid parliament to our emerging democracy. (Nzimande 1999)

An established tradition in political science is concerned with the relationship between participation and legitimacy. Among the few concerned with this matter in the politics of education, Hans Weiler observes that:

Participation is increasingly seen crucial source of legitimacy for policy decisions, especially in educational policy ... 'The basic argument is that if those likely to be affected by its results are involved in the policymaking process, the legitimacy of the process and its results will be enhanced. (Weiler 1985: 188-9).

The concept of participation is desperately in need of problematization in South African education. The following points, drawn from the cases in question, represent observations about the limitations of participation in South African education policymaking.

1. While groups are invited to participate, this does not mean that the views of the participants prevail, as was the case in the Hunter Commission Report where external consultants had the final say on scenario funding for public schools (Jansen 2000).

2. 'Even where participation in the initial debates has been very broad, the policies finally adopted may not have been widely discussed and criticised' (Samoff 1996: 12) A good example is the NCHE report which, as it moved from 'discussion document' status, to Green Paper, to draft White Paper, to White Paper, became less and less open to participatory and consultative inputs as a government document. This may reflect the changes in and micro-politics among key officials coming into the Department of Education since the publication of the $\mathrm{NCHE}$ report. And it almost certainly reflects the demise of the NCHE as an organization following the release of its report.

3. Participating groups have unequal power and expertise in different policy forums, leading to different kinds of emphases in policy outcomes. The role of students has consistently been marginalized in several of the cases under review e.g., the syllabus revision process. As a consequence, while students may appear as an invited constituency on these policymaking forums, they seldom show-up to participate in such bodies. A similar observation was made about the undue influence of apartheid bureaucrats in the syllabus revision process inciting existing legislation and procedures which extra- 
parliamentary and non-governmental groups could hardly contest given their historical alienation from the political and legal processes that shaped education.

4. Participation sometimes emerges at a point where the policy framework is already decided. For example, no teachers were involved in the decision to adopt outcomes based education as the preferred policy approach for a post- apartheid curriculum. But teachers were called on to become involved in the elaboration and implementation of $\mathrm{OBE}$, the decision to proceed having already been made.

5. Participation is sometimes confused with consultation, if the latter is described as a process of simply securing approval for final plans which may or may not be modified based on the consultative inputs received.

At some point, even participation becomes a threat to central authority. Under advice that the provinces constitute a problem with respect to the implementation of government policy, the current Minister of Education, Kader Asmal, spoke openly about this dilemma and his strategy to deal with it:

I will invoke 'co-operative governance' as the means for dealing with provinces, as provided by Section 100 of the Constitution. I will not ask for a constitutional amendment; that opens up other debates. But if I am responsible for norms and standards, then I am also responsible for the implementation of norms and standards. I will use political means to address this problem and seek legal advice. ${ }^{7}$

The point is that participation in policymaking and policy implementation invariably generates questions about the scope of authority of central government in relation to other authorities and constituencies. This principle holds both within the policymaking apparatus of government as well as outside of it. For this reason the first White Paper on Education and Training is at pains to distinguish the difference between the Ministry of Education (as political authority) and the Department of Education (as implementation agency for government policy). It also explains the caution with which Minister Bengu viewed competing, albeit allied, policy structures in the democratic movement:

From the perspective of government, I can say with assurance that we must not downgrade or undermine the policy capacity of the executive or legislative branch. But I can say with equal certainty, as political head of the ministry of education, that we need a strong, comradely, analytical, critical and advisory capacity within the heart of the movement itself, linked organically to the alliance structures. (Bengu 1998: 31)

The boundaries between authority and participation were clearly laid-down. The next question that needs to be addressed in this theorisation about the politics of policy is why the South African state would over-invest in the symbolism of policy and the policymaking process. There were important economic, political and legal or constitutional reasons for this stance towards policymaking in the years leading up to and since the first national democratic elections of 1994.

\section{Why the prominence of political symbolism?}


All nation states develop education policies with symbolic purposes in mind. But few would stress symbolic functions above practical considerations in the making of education policy. Why was this the case in South Africa during the fragile years of transition from apartheid (1994-9)?

First, the macro-economic environment within which the state had to operate was inimical to the kinds of redistributive policies declared in formal education policies. The adoption of GEAR (Growth, Employment and Redistribution) in June 1996 as macro-economic policy effectively put a cap on government spending. The reduction in state expenditure was one of the recurring themes of sate departments, led by the Finance portfolio, in an effort to ensure 'fiscal discipline'. Despite the claims that GEAR was also about equity and redistribution, in practice the goal of macroeconomic policy after apartheid was principally to ensure that 'the fundamentals are in place'. In the case of education, this meant that no signjficant levels of new funding would be allocated to this portfolio. There was therefore very little room to manoeuvre in putting 'policies into practice' in the years following the election. The Reconstruction and Development Programme (RDP), ${ }^{8}$ in this explanation, could therefore not be sustained since it quickly infused large amounts of new monies into education which was simply not sustainable in the inherited economic environment. Without surprise, the R DP office was shut down and its Minister 'redeployed' into another portfolio. In the absence of fiscal capacity to enact new policies in education, the state has no alternative but to resort to playing-up the symbolic value of policy. That is, that policies displayed rely heavily on stated claims to address inequalities, confront the apartheid legacy, promise equity, redress, democracy, transformation, quality, lifelong education and training, access for all, because the implementation capacity has been undermined by economic choices under GEAR.

Second, the political environment in which the state had to operate especially in the first two to four years before the former white National Party (the main opposition at the time) withdrew from the Government of National Unity, militated against any radical or redistributive thrust in policymaking. The case studies of policymaking show a clear distinction between those policies generated during early transition (the Hunter Report leading to the Schools Act of 1996) and those emanating from late transition, such s Curriculum 2005 (see Jansen 2000). Policies of early transition consciously attempted to reconcile white and middle class elements of post-apartheid society with government reform. The missive to 'consult as widely as possible' in the Hunter Commission and the allowance of unlimited fee-generation within former white schools were part of a political agenda of 'toenadering' (rapproachment) which found similar expression in other spheres of politics, the Rugby World Cup being perhaps the most dramatic example. Gradually, the imperatives of reconciliation gave way to a policy environment in which the state, at least politically, had more options with regard to radical and redistributive policy choices. The launching of OBE in the face of widespread public resistance could therefore be ignored and vilified by 1998 by state officials, a very different orientation from the $1994 / 5$ period when political accommodation was at a premium. What is clear, therefore, is that the discursive and symbolic value of policy held high currency in the immediate 
post-apartheid period, and this set strictures on the kinds of policy enactment which the state could launch in early transition.

Third, the symbolic value of policy gained capital as a consequence of the constitutional limitations imposed by the negotiated settlement with respect to the nine provinces. One of the most debilitating problems for the Ministry of Education during the transition was the circumscription of its power to setting 'norms and standards' for policy while the actual implementation of those policies were left to the nine provinces. Education policy implementation, in the legal discourse of the time, was a provincial competency. This meant that the central government was largely impotent to change the speed and direction of policy implementation in the provinces since it would require stepping-over a negotiated fine-line in the constitution between national powers and provincial competencies. To be sure, this dividing line was (and remains) a subject of contestation within government. Ahmed Essop, a senior government official in the Department of Education, maintained that the problem was self-imposed. By taking a conservative interpretation of the constitution, the Ministry of Education had in fact weakened its authority with respect to provincial regulation. This created problems for the ANC-led government on two fronts: the bureaucratic incapacity of most provinces to implement policy, and the political resistance of at least two provinces (governed by opposition parties) to any ANC-inspired radicalism in education policy.

A consequence of this standoff on provincial competencies was the constant rivalry over policy and its implementation between the central government (led by the ANC) and the provincial government of KwaZulu Natal province (led by the Inkatha Freedom Party). National Minister of Education, Sibusiso Bengu, and his povincial counterpart, MEC ${ }^{10}$ Vincent Zulu, found themselves in regular and consistent public brawls, the most prominent concerning the implementation of education policy in the province. Similar struggles were okayed-out between the National Ministers of Education (ANC appointments) and a succession of provincial MECs in the Western Cape province (National Party appointments) on matters including the teacher redeployment scheme; interestingly, the person who led the resistance among white schools against redeployment (Helen Zille, then Chairperson of the Governing Body of Grove Primary), is now the MEC for Education in the same province. The one area in which government did intervene, was in the making of the post-apartheid budget. Withholding or setting limits on budgetary disbursements from central government to the provinces, the Ministry of Education (Working in concert with the ANC Minister of Finance), was able to extract some concessions from unwilling or incapacitated provinces. However, there was little leverage through this route on policy implementation. In sum, the inability of the central government to leverage change in educational practice simply added value to a policy regime reliant on symbolic representations of what could or should be achieved in the educational domain.

Fourth, there is little evidence that the ANC, moving into government, was able to change the rhetorical and militant position of policy into the kinds of technical and political skills required for changing the complex educational 
landscape inherited from apartheid. As often observed by commentators, South Africa inherited a political bureaucracy rather than a technical bureaucracy. The reliance on symbols worked well within liberation movements (see Seekings 2000: 23) but can undermine effective policy generation and implementation when such movements run real governments in the context of pressing local and global constraints (Friedman 1992). The unrealistic promises in the prefaces and substance of each of the major education policy documents governing the seven case studies (Jansen 2000) is evidence of such unreality with the post-apartheid state. The lack of material support for articulated policy positions (such as Curriculum 2005) has been extensively described in the case studies. And the ongoing rhetoric about change, even in the face of demonstrated setbacks, is further evidence of a historical conditioning that relies on symbolic politics among the new governing elite. Indeed, 'Because symbolic politics is so powerful, it still sets the parameters in which the key actors move' (Friedman 1992: 612).

\section{What are the dilemmas and possibilities of understanding symbolism as political craft?}

I have proposed that we rethink policymaking under conditions of third world transition. This argument is partly a response to two lacunae in the available literature.

The literature on political symbolism in education policy is particularly scant, and heavily favours technical analyses of policymaking. The authoritative publication by Sabatier (1999) on Theories of the Policy Process completely ignores the symbolic power of policymaking. In comparative education, another recent and authoritative account of policy processes in education, by Anthony Hargreaves (1998) and his colleagues, completely ignore third world transitions as a site for investigating the politics of education policymaking. It is this under-exploration of a potentially powerful theoretical construct in third world sites that led to this particular framework being applied to education policymaking after apartheid.

One of the most comprehensive studies supporting the view of 'policy as political symbolism' emerged from a study by Frederik Hess (1997) insightfully titled 'Initiation without Implementation: Policy Chum and the Plight of Urban School Reform'. From a sophisticated study of reform initiatives in 57 urban school districts in the USA, Hess concludes that:

\footnotetext{
the status quo in urban school systems is largely due to political incentives which produce a surfeit of reform and insufficient attention to implementation. In fact, the continuing initiation of reform efforts is the status quo. The result is that successive generations of partially implemented reforms produce instability, waste resources, and alienate faculty. (Hess 1997: i)
}

What is striking about the Hess study is the fact that the lack of implementation was not because of a lack of resources; that the evidence for non-implementation spread across 57 large school districts; that the data were collected on the basis of at least five different kinds of school reform; 
and that the data were collected through intensive methods including 342 interviews. Against this background, Hess argues that 'Reforms tend to be symbolically attractive but not to impose the costs required by significant change' (Hess 1997: 7) and 'The result is that policymakers have worked more diligent on appearing to improve schooling than on actually doing so' (Hess 1997: 9).

The reason for this extensive referencing of the Hess study is that it represents one of the very few empirical studies making a similar case to what I presented in a context where resources and capacity are not the prime explanatory variables for non-implementation. My contention is that unless policy evaluation in South Africa provides greater weight to the symbolic functions of education policy, then there is the real danger of social expectations being frustrated and theoretical progress being undermined in explaining education transition after apartheid.

But how much weight should be assigned to policy symbolism as explanation for non-reform in South African education after apartheid? On the evidence presented in this study, I have argued that during early transition (19941999) the primary explanation for non-change lies in the symbolic arena. Now I should be clear: this does not mean that policy formulation was 'mere words'. The notion of policy as 'mere words' has little theoretical or practical value. As Rosa Nidia Buenfil-Burgos stridently argues:

In spite of the fact that educational policies (e.g., globalising policies) do not reach schools and other educational environments is exactly as they were proposed, they nevertheless leave a trace in day-to-day local educational practices. This is a position [that]...challenges the ordinary idea that policies are discourses (i.e.,just words) which have nothing to do with everyday practices (i.e., reality). (Buenfil-Bugos 2000: 1)

Words have meaning and purpose. Discourses have political intent. To dismiss the theoretical position of policy as political symbolism to mean the simple issuing of words would be to miss the point. Other studies, recently completed in England, New Zealand and Canada come to the same striking conclusion about the political meaning and consequences of policy language; in the words of Levin and Young, 'our analysis supports a view of official rhetoric as being primarily symbolic and intended to create or support particular definitions of problems and solutions' (Levin and Young 2000: 189, see also Edwards and Nicoll 2001).

In addition, I would be remiss not to recognize the real hazards of 'practical constraints', A critical reader of an earlier draft of this paper makes the point emphatically:

In his final sentence the writer introduces the KEY to educational change... which I would like to have seen stressed at regular intervals throughout the text. It is not only because of stressing SYMBOLIC POLICY changes that the educational system has not been able to really change in a more widespread and generally beneficial manner, but because, inter alia, of the financial constraints on all sides. (Emphasis in the original) 
My argument has not been that financial constraints are irrelevant. Rather, I have made the case for a different interpretation of the role of constraints in relation to policy choices. I have argued that it is precisely because of material constraints on policy that the state has been inclined to play-up the symbolic role of policy rather than its practical consequences. However, the converse is not necessarily true: that if there were no material constraints, policy would be implemented as planned. Rich accounts of policy reform (see Hargreaves et a!. 1998) over a century of effort have put paid to the idea of searching for fidelity between policy and practice. Nevertheless, the room to maneuver in policy reform is substantially constrained by the extent to which material resources are available to educational planners.

Having said all of this, the original point of departure for my thesis on political symbolism is that politicians do not always invent policy in order to change practice. It often represents a search for legitimacy. In this regard another critical reader, in an insightful set of comments, makes the point that:

\begin{abstract}
the central policy issue which the new government inherited from its predecessor was the illegitimacy of the system as a whole. The establishment of legitimacy was no easy matter even at the level of symbolic manipulations. . . Certainly part of the contestation was about gaining influence and power but the currency of exchange was educational vision and the policy arena was thronged with gatekeepers and 'analysts' who were ready to block and discredit the attempts to construct any sort of comprehensive policy.
\end{abstract}

While I might disagree with Morphet as to whether legitimacy was 'the central policy issue' (especially for the ANC with its overwhelming electoral mandate), I would certainly share the view that establishing the credentials of the new system required an overarching symbolic discourse about transformation (captured in key words like equity, non-racialism, democracy and redress). But this modification proposed by Morphet (and which I accept) merely extends the argument that policy formulation was not always about changing practice, but was weighted towards important symbolic considerations which Ihron Rensburg (in the main text) considered strategic for the early period.

Now this does not mean that the planning apparatus in the Department of Education did not entrench itself within a daily grind of policy formation. Policy bureaucrats, have the task of giving implementation substance to official policy - whether they agree with such policy or not; whether they think it is implementable or otherwise. Indeed, the recently completed Review of Curriculum 2005 appears to be a recognition by both the Minister of Education and some of his departmental planners of the very real practical constraints facing the implementation of a complex and demanding school curriculum (Chisholm 2000), and this courageous act of 'review' could lead to a more 'streamlined' policy for curriculum change. At the same time, the fact that the Cabinet became involved in and scaled-down some of the proposals of the review team (after the Minister accepted it) is itself testimony to the symbolic politics underpinning something that from a bureaucratic point of view, appears to be a straightforward technical matter (see Jansen 2001). 
Finally, the theory of political symbolism does not discount the possibility that education policies have resulted in some degree of positive change within the education system. Policies, as noted earlier, leave a trace in practice. I cannot but agree with yet another critical reader that 'I have seen little miracles of change, of new life...though the success stories are not the work only of government'. If anything, the debate on Curriculum 2005 was successful because it generated for the first time in South African history, a wide public debate about curriculum and pedagogy. Furthermore, well-resourced schools were able to respond to the new curriculum through innovative changes in classroom pedagogy. But as our research has demonstrated elsewhere, these effects may have been unintended and worked largely (though not exclusively) to the benefit of schools already privileged with well-qualified teachers and a stock of inherited material resources (Maqutu, Khumalo, Jairam and Jansen 1999). But these uneven, unexpected, and small-site changes do not discount the observation that at a system-wide level, education remains steeped in crisis and inequality despite the flurry of policy in the six years since the first democratic elections. This acknowledgment of crisis was made, significantly, by the second ANC Minister of Education, Kader Asmal, in his Call to Action in late 1999. And it is this reality that cannot be explained away by the useful but limited instance of 'success stories.'

\section{Acknowledgements}

This study has incurred many debts. I wish to acknowledge the financial and intellectual support of the Centre for Development and Enterprise during my tenure as Research Associate (1999-2000), in making this paper possible. I also thank my research assistant, Lucky Khumalo, and my two excellent administrative assistants, Shakila Thakupersad (University of Durban Westville) and Yvonne Munro (University of Pretoria) for support in data management and administration of this project.

\section{Notes}

I. The larger study ${ }^{1}$ referred to (Jansen 2000) bears the title 'Framing Education Policy Under Apartheid: On the Polities of Non-Reform in South African Education, 1990-2000' (Johannesburg: Centre for Development and Enterprise).

2. People's Education was a movement in the 1980s of students, teachers, parents and unionists to create an alternative education to the then apartheid education system dominating the South African political landscape.

3. I realize that, of course, 'independence' is a contested term in reference to South Africa. In this Context I simply refer to the formal end of white political rule in 1994.

4. Dr Blade Nzimande, a prominent education and political activist, was also the influential member of the Parliamentary Portfolio Committee on Education, under the Mandela Presidency.

5. The Tripartite Alliance involved the African National Congress, the South African Communist Party, and the Congress of South African Trade Unions. 6. The one possible exception was the work of the NCHE. As Samoff (1996) notes, 'the Commission was diverse but not fully inclusive. None of the commissioners, for example, was a student' (p.14). This may explain the 'minor revolt' by student constituencies on the release of the report while it 
was being feted in Salzburg (Cloete and Muller 1998).

7. Discussion during the so-called 'listening campaign' with the Education Policy Units, July 1999.

8. The RDP was the initial programme of Government shortly after the first democratic elections of April 1994, with a strong social distribution programme backed by the powerful South African Congress of Trade Unions.

9. On this occasion in 1996, Nelson Mandela donned the No.6 rugby jersey of the South African Captain and walked onto the Ellis Park Stadium in

Johannesburg where South Africa was playing New Zealand in the first Rugby

World Cup after the end of apartheid. This symbolic gesture of a black

President entering the sporting world of white South Africa, was perhaps the most poignant moment in the politics of reconciliation during the nervous years following the end of white minority rule.

10. Literally, Member of the Executive Council (MEC) of the provincial legislature; in everyday usage, provincial MECS were referred to as 'Ministers' of whatever the portfolio in question.

\section{References}

AFRICAN NATIONAL CONGRESS (1994) A Policy Framework for Education and Training (Johannesburg: ANC Education Department).

ASMAL, K. (1999) Call to Action: Mobilising Citizens to Build a South African Education and Training System for the $21^{\text {st }}$ Century (Statement by Professor Kader Asmal, Minister of Education, Tuesday 27July).

BENGU, S. M. E. (1999) Developments in Education since the 1994

Elections: Our Current Challenges and Plans for the Future (Report on the National Policy Review Conference on Education and Training, 9-12 October, Johannesburg, pp. 29-38).

BUENFIL-BURGOS, R. N. (2000) Globalization, education and discourse political analysis: ambiguity and accountability in research, International Journal of Qualitative Studies in Education, 13(1), 1-24.

CHISHOLM, LINDA (2000) (ed) A South African Curriculum for the $21^{\text {st }}$ Century. Report of the Review Committee on Curriculum 2005 (Department of Education, Pretoria, 31 May).

CHISHOLM, L. and FULLER, B. (1996) Remember people's education? Shifting alliances, state-building and South Africa's narrowing policy agenda, Journal of Education Policy, 11(6), 693-716.

CLOETE, N. and MULLER, J. (1998) South African higher education reform: what comes after post-colonialism? European Review, 6 (4), 525-542.

DALE, R. (1999) Specifying globalisation effects on national policy: a focus on mechanisms, Journal of Education Policy, 14(1), 1-17.

DEPARTMENT OF EDUCATION (1996) The Organisation, Governance and Funding of Schools: Education White Paper 2 (Pretoria: Government Gazette, vol. 368, no. 16987 (February 1996), notice 130 of 1996).

DEPARTMENT OF EDUCATION (1995a). Education and Training in a Democratic South Africa: First Steps to Develop a New System (White Paper on Education and Training. Government Gazette vol. 357, no. 16312 (15 March 1996), notice 196 of 1995).

DEPARTMENT OP EDUCATION (1995b). Report of the Committee to Review the Organisation, Governance and Funding of Schools (Pretoria, 31 
August).

DIPHOFA, M., VINJEVOLD, P. and TAYLOR, N. (1999) Introduction, in N.

Taylor and P. Vinjevold (eds) Getting Learning Right. Report of the

President's Education Initiative Research Project (Johannesburg: The Joint

Education Trust), pp. 1-12.

EDWARDS, R. and NICOLL, K. (2001) Researching the rhetoric of lifelong

learning , Journal of Education Policy, 16 (2), 103-112.

FRIEDMAN, S. (1992) Beyond symbols? the politics of economic

compromise, in R. Schrire (ed.) Wealth or Poverty? Critical Choices for South

Africa (Cape Town: Oxford University Press), 608-622.

HALPIN, D. and TROYNA, B. (1995) The politics of education policy

borrowing, Comparative Education, 31(3), 303-310.

HARGREAVES, A. et al. (1998) International Handbook of Educational

Change (Great Britain: Kluwer Academic Publishers).

HARTSHORNE, K (1999) The Making of Education Policy in South Africa

(Cape Town: Oxford University Press Southern Africa).

HESS, F. (1997) Initiation without implementation: policy churn and the plight of urban school reform, Paper prepared for the Conference on Rethinking

School Governance at the Kennedy School of Government (Harvard

University, Cambridge, Massachusetts, USA 12-13 June).

JANSEN, J. D. (2001) Symbols of Change, Signals of Conflict, in A. Kraak and M. Young (eds) The Implementation of Education Policies, 1990-2000

(Pretoria: Human Sciences Research Council), forthcoming.

JANSEN, J. D. (2000) Framing Education Policy After Apartheid: On the

Politics of Non-Reform in South African Education, 1990-2000

(Johannesburg: Centre for Development Enterprises).

JANSEN, J. D. (1998) Curriculum reform since Apartheid: intersections of

policy and practice in the South African transition, Journal of Curriculum

Studies, 31 (1), 57-67.

JANSEN, J. D. (1999) Grove Primary: power, privilege and the law in South

African education, Journal of Education, 23(1), 5-30.

JANSEN, J. D. and CHRISTIE, P. (1999) Changing Curriculum: Studies of

Outcomes Based Education in South Africa (Cape Town: Juta Academic

Publishers).

JANSEN, J. D. and NAIDOO, J. (1996) National Evaluation of the Culture of

Learning Programme. Final Report (Department of Education: Pretoria).

KAHN, M.J. (1996) Five years gone: a case study of education policy

implementation in the transition to democracy in South Africa, International

Journal of Educational Development, 16 (3), 281-289.

KALLAWAY, P., KRUSS, G., FATAAR, A. and DONN, G. (1998) (eds)

Education After Apartheid: South African Education in Transition (Cape Town: University of Cape Town Press, first published 1997).

KRAAK, A. (1998) Competing Education and Training Policies: A 'systematic' versus 'unit standards' approach (Pretoria: Human Sciences Research

Council, Occasional Papers Series, 1998/1).

LEVIN, B. and YOUNG, J. (2000) The Rhetoric of Educational Reform, Journal of Comparative Policy Analysis: Research and Practice, 2: 189-190. LODGE, T. (undated). Policy processes within the ANC and the Tripartite Alliance. Unpublished paper, Johannesburg. 
MAHARAJ, G. (1999) (ed.) Between Unity and Diversity: Essays on NationBuilding in Post-Apartheid South Africa (Cape Town: IDASA and David Philip Publishers).

MANGANYI, N. C. (2001) Public Policy and the Transformation of Education in South Africa, in Y. Sayed and J. D. Jansen (eds) Implementing Education Policy in South Africa (Cape Town: University of Cape Town Press).

MAQUTU, T., KHUMALO, L.,JAIRAM, A. and JANSEN,J. D. (1999). A Study on the Implementation of Outcomes Based Education in Grade 1 Classrooms (University of Durban Westville, Centre for Education Research, Evaluation and Policy).

MCLAUGLIN, M. (1998) Listening and learning from the field: tales of policy implementation and situated practice, in A. Hargreaves et al. (1998)

International Handbook of Educational Change (Great Britain: Kluwer Academic Publishers), pp. 70-84.

MATHOLE, A. (1998) Response to Rensburg (Report on the National Policy Review Conference on Education and Training, 9-12 October, Johannesburg), pp. 66-67.

NZIMANDE, B. (1999) Interview on the rule of parliament in making and contesting education policy, September. Appears as Chapter in, Y. Sayed and J. D. Jansen (eds) Implementing Education Policies: The South African Experience (Cape Town: UCT Press).

PENDLEBURY, S. and ENSLIN, P, (1999) Transforming education in South Africa, Cambridge Journal of Education, 28 (3), 26 1-268.

RENSBURG, I. (1998) Qualifications, Curriculum, Assessment and Quality Improvement: Laying the Foundations for Lifelong Learning (Report on the National Policy Review Conference on Education and Training, 9-12 October, Johannesburg), pp. 49-59.

SABATIER. P. A. (1999) (ed.) Theories of the Policy Process (Boulder, Colorado, USA: Westview Press).

SEEKINGS, J. (2000). The UDF: A History of the United Democratic Front in South Africa, 1983-1991 (Cape Town: David Philip Publishers).

SAMOFF, J. (1996) Frameworks! South African Education and Training Policy Documents, 1994-1996 (Macro-Education Policy Unit, University of Durban Westville).

SAYED, Y. and JANSEN, J. D. (2001) (eds) Implementing Education Policies: The South African Experience. (Cape Town: University of Cape Town Press). WEILER, H. (1985) Politics of educational reform, in R. L. Merritt and A.J. Merrit (eds) Innovation in the Public Sector (Beverly Hills: SAGE Publications), pp. 167-199.

Copyright of Journal of Education Policy is the property of Ltd and its content may not be copied or emailed to multiple sites or posted to a listserv without the copyright holder's express written permission. However, users may print, download, or email articles for individual use. 